\title{
Fatty acid profile of goat milk in diets supplemented with chia seed (Salvia hispanica L.)
}

\author{
B. Schettino, ${ }^{*}$ S. Vega, ${ }^{*}$ R. Gutiérrez, ${ }^{*}$ A. Escobar,† J. Romero,‡ E. Domínguez,‡ \\ and M. González-Ronquillo* $\ddagger^{1}$ \\ *Departamento de Producción Agrícola Animal, Universidad Autónoma Metropolitana Xochimilco, Calz. Hueso 1100, Villa Quietud, \\ 04960 Coyoacán, Cd. de México, México \\ †Departamento de Producción Agrícola y Animal, Centro Nacional de Sanidad Agropecuaria (CENSA), \\ Universidad Autónoma del Estado de México, Xochimilco, 04960 Coyoacán, Cd. de México, México \\ ‡Facultad de Medicina Veterinaria y Zootecnia, Universidad Autónoma del Estado de México, Instituto Literario 100 Ote., 50000, Toluca, \\ Estado de México, México
}

\begin{abstract}
Chia seed (Salvia hispanica L.) is the greatest known plant source of $n-3 \alpha$-linolenic acid. The present study evaluated the effects of 3 inclusion levels of chia seed [zero (control); low, 2.7\% (CLow); and high, 5.5\% (CHigh)] in diets of dairy goats on milk yield and fatty acid profile. Nine Saanen dairy goats in the last third of lactation period, live weight $38 \pm 8.7 \mathrm{~kg}$, housed in metabolic cages, were fed iso-proteic and iso-energetic (160 g of crude protein/d and 11 MJ of metabolizable energy/d) diets. Gas chromatography was used to analyze fatty acid profile and total conjugated linoleic acid (CLA). Silver ion HPLC was used to analyze the isomeric profile of CLA. The results were subjected to variance analysis using a Latin square design repeated $3 \times 3$. The CHigh treatment was higher for dry matter, neutral detergent fiber, and acid detergent fiber intake compared with CLow and control diets. Digestibility was not affected by the inclusion of chia seeds. The CHigh diet improved $\mathrm{N}$ intake with respect to the control and CLow diet. Milk yield and chemical composition were not affected by the treatment. The milk fatty acid profile of C18:0, C18:1, C18:2, and C:20 was higher for CHigh than the other treatments. The in vitro gas production ( $\mathrm{mL}$ of gas/g of dry matter) was lower in CHigh than the control diet. In conclusion, the addition of chia seeds at the CHigh level in dairy goat diets negatively affected in vitro rumen fermentation, but increased the milk fatty acid profile of C18:0, C18:1n-9 cis, and C:20, monounsaturated fatty acids, and polyunsaturated fatty acids. The total CLA content
\end{abstract}

Received February 22, 2017.

Accepted April 9, 2017.

${ }^{1}$ Corresponding author: mrg@uaemex.mx increased from 0.33 to $0.73 \%$ with the supplementation of chia to the diet, as well as the isomers cis-9,trans-11, trans-7, cis-9, trans-11, cis-13, and trans-12,trans-14.

Key words: chia seed, in vitro gas production, conjugated linoleic acid, fatty acid, dairy goat

\section{INTRODUCTION}

Dairy foods have been proven to be an excellent source of beneficial metabolites, such as CLA, n-3 and n-6 fatty acids (FA), antioxidants, phenols, flavonoids, and bioactive peptides (Dewhurst et al., 2006; Hilario et al., 2010; Prandini et al., 2011). However, some studies have discouraged the consumption of foods of animal origin because of the potential negative health consequences of ingesting large amounts of SFA and cholesterol. Therefore, some indices have been developed to better describe the benefits and risks of foods for human consumption, calculated from the FA profile and SFA and cholesterol content (Connor et al., 1986; Ulbricht and Southgate, 1991; Chen et al., 2004).

Goat milk is of particular economic interest in certain areas of the world. The production of this type of milk can be considered an alternative for consumers who have some type of sensitivity or allergy to dairy cow products (Luna et al., 2008) as well as being used in the preparation of cheeses. One of the most important aspects of goat milk is its high content of $\mathrm{C} 6: 0, \mathrm{C} 8: 0$, and C10:0, which compose 18\% of goat milk (Adlof, 2003). Medium-chain triglycerides normally reach a percentage of $36 \%$ in goat milk in comparison with $21 \%$ in cow milk, thereby reducing the synthesis of endogenous cholesterol (Haenlein, 2004).

Different FA have potential benefits for human health, such as rumenic acid (RA; cis-9,trans-11 C18:2), a principal isomer of CLA, with positive effects in the prevention of cancer and atherosclerosis (Aydin, 2005). The RA content may vary due to factors such as 
Table 1. Chemical composition (means $\pm \mathrm{SD}$ ) of the ingredients used in the diet $(\mathrm{g} / \mathrm{kg}$ of DM, unless otherwise indicated) of dairy goats supplemented with chia seeds

\begin{tabular}{|c|c|c|c|c|c|}
\hline Item & Chia seeds & Corn grain & Soybean meal & Barley hay & Corn silage \\
\hline \multicolumn{6}{|l|}{ Ingredient } \\
\hline $\mathrm{DM}(\mathrm{g} / \mathrm{kg}$ of fresh matter $)$ & $966 \pm 58$ & $932 \pm 46$ & $923 \pm 48$ & $920 \pm 41$ & $198 \pm 10$ \\
\hline Fat & $291 \pm 11$ & $271 \pm 10$ & $12 \pm 0.5$ & $10 \pm 0.4$ & $17 \pm 0.8$ \\
\hline NDF & $558 \pm 33$ & $46 \pm 3$ & $70 \pm 4$ & $565 \pm 22$ & $545 \pm 32$ \\
\hline $\mathrm{ADF}$ & $285 \pm 14$ & $23 \pm 1$ & $37 \pm 2$ & $313 \pm 15$ & $322 \pm 16$ \\
\hline $\mathrm{C} 16: 0$ & $6.64 \pm 0.29$ & $13.02 \pm 5.72$ & $15.80 \pm 0.79$ & $35.73 \pm 1.69$ & $19.82 \pm 0.82$ \\
\hline C18:0 & $3.21 \pm 0.14$ & $2.56 \pm 0.12$ & $4.41 \pm 0.19$ & $5.28 \pm 0.26$ & $3.47 \pm 0.16$ \\
\hline C18:1n-9 cis & $6.44 \pm 0.34$ & $33.92 \pm 1.69$ & $19.40 \pm 0.87$ & $39.30 \pm 1.96$ & $19.56 \pm 0.93$ \\
\hline C18:2n-6 & $24.49 \pm 1.47$ & $49.54 \pm 2.97$ & $52.93 \pm 2.43$ & $19.71 \pm 1.08$ & $48.80 \pm 2.73$ \\
\hline C18:3n-3 & $59.20 \pm 2.29$ & $0.95 \pm 0.04$ & $7.47 \pm 0.41$ & $0.00 \pm 0.0$ & $8.35 \pm 0.45$ \\
\hline
\end{tabular}

${ }^{1}$ Calculated by Ewing (1997).

the production systems used and the supplementation of lipids to the diet with oils or oilseed, which contain PUFA, modifying the FA profile, principally those of long-chain UFA (Chilliard et al., 2007).

Chia seed (Salvia hispanica L.), native to Mexico and Guatemala, has a high content of $\alpha$-linolenic, linoleic, oleic, and stearic FA (Alvarez et al., 2008; Azcona et al., 2008) and could thus be an alternative in the diet of goats. The technique of in vitro gas production (Menke and Steingass, 1988; Theodorou et al., 1994) can be used to estimate the kinetics of fermentation of food in ruminant feed, in calculating its rumen degradation and interaction with rumen microorganisms. The objective of the present study was to determine the intake, digestibility, production, and composition of FA of goat milk, for goat diets supplemented with chia seed (Salvia hispanica L.).

\section{MATERIALS AND METHODS}

\section{Animals, Experimental Design, and Diets}

The present study was carried out at the Animal Science farm of the School of Veterinary Medicine and Animal Science of the Universidad Autonoma del Estado de México. Nine Saanen dairy goats in the last third of lactation were used, with a live weight $(\mathbf{L W})$ of $38 \pm 8.7 \mathrm{~kg}$; the goats were kept in metabolic cages $(1.20 \times 0.80 \mathrm{~m})$. Three treatments were established: a control diet with no inclusion of chia seeds, and 2 levels of inclusion of chia seeds: low (CLow) with $2.7 \%$ and high (CHigh) with 5.5.

The diets were formulated to be iso-proteic and isoenergetic (160 g of $\mathrm{CP} / \mathrm{d}$ and $11 \mathrm{MJ}$ of $\mathrm{ME} / \mathrm{d}$ ) (NRC, 2007). The chemical composition of the ingredients is shown in Table 1. The diet was based on forage (barley hay and corn silage) and concentrate (corn grain and soybean meal) supplemented with vitamins and minerals (Malta Multitec) and different inclusion levels of chia seed (Table 2). The concentrate and the proportion of feed were mixed, and the animals had free access to drinking water. Animals were fed at 0800 and 1600 $\mathrm{h}$ daily. The adaptation period to the diets was $15 \mathrm{~d}$ followed by $5 \mathrm{~d}$ of sampling, recording feed intake and the amount of feces, urine, and milk excreted daily. Samples of feed, feces, and urine (10\%) were frozen at $-20^{\circ} \mathrm{C}$ until analysis.

\section{Chemical Composition of the Diets}

To determine the DM content of feed, refusals and feces, samples were dried in a forced-air oven $\left(60^{\circ} \mathrm{C}\right.$, $48 \mathrm{~h}$ ), and subsequently ground in a Wiley mill $3 \mathrm{~mm}$ diameter (Arthur H. Thomas, Philadelphia, PA). Organic matter was determined by incineration $\left(550^{\circ} \mathrm{C}\right.$ for $3 \mathrm{~h}$ ), fat, total nitrogen (AOAC International, 2005), and $\mathrm{CP}$ content. The NDF and ADF were determined using the ANKOM technique (Van Soest et al., 1991) with $\alpha$-amylase and uncorrected for ash. Milk samples were analyzed using a MilkoScan 133B (Foss Electric, Hillerød, Denmark) to obtain the values of protein, fat, TS, and SNF. Fatty acids of the dietary components were separated by the Soxhlet method (AOAC International, 2005).

\section{In Vitro Gas Production}

The in vitro gas production technique (Theodorou et al., 1994) was used to determine the kinetics of rumen fermentation. Three rumen cannulated lactating goats were used as donors of rumen fluid (LW of $40 \pm 3 \mathrm{~kg}$; $\pm \mathrm{SD})$ and fed the control diet. Equal amounts of ru- 
men fluid were collected and filtered through 4 layers of cheesecloth. The buffer solution was prepared according to the technique of Menke and Steingass (1988), in which $0.800 \mathrm{~g}$ of $\mathrm{DM}$ of each ingredient and each diet mixture were incubated in glass flasks of $125 \mathrm{~mL}$, to which $90 \mathrm{~mL}$ of buffer solution and $10 \mathrm{~mL}$ of rumen fluid were added, to make 3 bottles per sample. Two additional bottles without substrate were also prepared as blanks to adjust for the potential contribution of other solubles in the extracts on overall gas production and to correct readings of substrate, including bottles from self-fermentation of rumen inocula. The bottles were incubated in a water bath at $39^{\circ} \mathrm{C}$. The gas volume was recorded at $3,6,9,12,24,36,48,72$, and 96 $\mathrm{h}$ of incubation in 3 series of incubation. Gas production was registered by means of a pressure transducer (Delta Model HD 8804, Caselle di Selvazzano, Italy). After incubation, the samples were filtered and dried $\left(48 \mathrm{~h}, 65^{\circ} \mathrm{C}\right)$ to measure the proportion of dry matter disappearance (DMd). Gas production at $96 \mathrm{~h}$ was correlated with DMd to calculate relative gas production (RGP, mL gas/g of DMd).

The kinetic parameters of gas production (GP) were estimated through an iterative procedure of nonlinear regression analysis (PROC NLIN, 2002, version 8.2,
SAS Institute Inc., Cary, NC) according to Krishnamoorthy et al. (1991), calculated as

$$
\mathrm{GP}=\mathrm{B}\left(1-\mathrm{e}^{-\mathrm{C}(\mathrm{t}-1)}\right)
$$

where GP is the volume of gas ( $\mathrm{mL}$ of gas/g of DM) at time $\mathrm{t}, \mathrm{B}$ is the asymptotic GP $(\mathrm{mL} / \mathrm{g}$ of $\mathrm{DM}), \mathrm{C}$ is the fractional rate of GP $(\mathrm{g} / \mathrm{h})$, and $\mathrm{l}(\mathrm{h})$ is the discrete lag time before gas production.

\section{Fatty Acids in Milk}

Milk fat was extracted using the procedure described by Frank et al. (1975); $250 \mathrm{~mL}$ of milk sample was placed in a volumetric flask of $500 \mathrm{~mL}$, and $250 \mathrm{~mL}$ of detergent solution [50 g of sodium hexametaphosphate and $24 \mathrm{~mL}$ of Triton X-100 (Hycel, México) dissolved in $1 \mathrm{~L}$ of water] was added. The flask was agitated vigorously and placed in a water bath at $90^{\circ} \mathrm{C}$. The flask was inverted every 15 min until a clear suspension of the fatty material was obtained in the neck of the flask. The extracted fat was filtered at $50^{\circ} \mathrm{C}$ through number 4 Whatman paper in the presence of anhydrous sodium sulfate, and conserved in glass tubes at $-20^{\circ} \mathrm{C}$ until analysis.

Table 2. Ingredients ( $\mathrm{g} / \mathrm{kg}$ as fed, $\mathrm{DM})$ and proportions used in formulating rations for dairy goats $(\mathrm{g} / \mathrm{kg}$ of $\mathrm{DM}$ ) of the control, $2.7 \%$ chia seed supplementation (CLow), and $5.5 \%$ chia seed supplementation (CHigh) dietary groups (means $\pm \mathrm{SD}$ )

\begin{tabular}{lccc}
\hline & & Dietary group \\
\cline { 2 - 4 } Item $^{1}$ & Control & CLow & CHigh \\
\hline Ingredient & & & \\
Corn silage & 350 & 350 & 350 \\
Chia seeds & 0 & 27 & 55 \\
Corn grain & 271 & 254 & 236 \\
Barley hay & 231 & 104 & 94 \\
Soybean meal & 114 & 34 & 34 \\
MVS & 34 & $879 \pm 39$ & $880 \pm 46$ \\
Chemical composition & & $856 \pm 37$ & $859 \pm 44$ \\
DM (g/kg of fresh matter) & $877 \pm 42$ & $24 \pm 1$ & $161 \pm 7$ \\
OM & $156 \pm 7$ & $254 \pm 10$ & $32 \pm 1$ \\
CP & $17 \pm 1$ & $138 \pm 6$ & $149 \pm 10$ \\
Fat & $232 \pm 11$ & $11.0 \pm 0.3$ & $11.0 \pm 0.4$ \\
NDF & $127 \pm 5$ & & \\
ADF & $11.0 \pm 0.3$ & $3.6 \pm 0.16$ & $20.1 \pm 1.0$ \\
ME (MJ/kg of DM) & & $3.6 \pm 0.15$ \\
Fatty acid composition (\%) & $3.6 \pm 0.15$ & $26.1 \pm 1.12$ \\
C16:0 & $27.3 \pm 1.13$ & $26.7 \pm 1.23$ & $39.6 \pm 2.05$ \\
C18:0 & $41.1 \pm 2.13$ & $40.4 \pm 2.10$ & $7.1 \pm 0.32$ \\
C18:1n-9 cis & $4.0 \pm 0.17$ & $5.5 \pm 0.23$ & \\
C18:3n-3 (LNA) & ALA) & & \\
\hline
\end{tabular}

${ }^{1}$ MVS = mineral-vitamin supplement: Malta Multitec $(1.0 \mathrm{~kg}$ of DM; MaltaCleyton, Texcoco, Estado de México) containing $25 \mathrm{mg}$ of antioxidant, $4.5 \mathrm{~g}$ of calcium carbonate, $6 \mathrm{~g}$ of salt, $30 \mathrm{~g}$ of ionophore, $50 \mathrm{~g}$ of zinc oxide, $6 \mathrm{~g}$ of sodium bicarbonate, $6 \mathrm{~g}$ of copper sulfate, $20 \mathrm{~g}$ of ferrous sulfate, $125 \mathrm{~g}$ of sodium sulfate, and 18,000 IU of vitamin E, 3,000,000 IU of vitamin A, 3,750,000 IU of vitamin D, $140 \mathrm{~g}$ of potassium chloride, $0.500 \mathrm{~g}$ of ethylene diamine, $0.090 \mathrm{~g}$ of cobalt carbonate, $500 \mathrm{mg}$ of magnesium oxide, $36 \mathrm{~g}$ of manganese oxide, and $0.090 \mathrm{~g}$ of selenium. LNA $=$ linoleic acid; ALA $=\alpha$-linolenic acid. 


\section{Chromatographic Analysis for Fatty Acids}

The preparation of the FAME was carried out according to the procedure ISO-IDF (2002). These were analyzed in a gas chromatograph with flame ionization detector, Shimadzu GC-2010 Plus (Shimadzu, Kyoto, Japan), with auto-injector, Split (1:100). A capillary column CP-Sil 88 Supelco $\left(\mathrm{SPTM}^{2560}\right.$, Fused Silica, Cat. No. 24056; Supelco, Bellefonte, PA) was used with $100 \mathrm{~m} \times 0.25 \mathrm{~mm}(\mathrm{di}) \times 0.20 \mu \mathrm{m}$ film thickness, using a temperature gradient program. Nitrogen was used as gas carrier; the temperatures of the injector and detector were 250 and $270^{\circ} \mathrm{C}$, respectively. The initial temperature of the oven was $140^{\circ} \mathrm{C}$, which was maintained for $5 \mathrm{~min}$. The temperature was then increased by $5^{\circ} \mathrm{C} / \mathrm{min}$ to $195^{\circ} \mathrm{C}$ and maintained for $1 \mathrm{~min}$. It was increased by $6^{\circ} \mathrm{C} / \mathrm{min}$ until reaching $220^{\circ} \mathrm{C}$ and was maintained at that temperature for $20 \mathrm{~min}$; then it was increased by $5^{\circ} \mathrm{C} / \mathrm{min}$ until reaching $249^{\circ} \mathrm{C}$ and was maintained at that temperature for $5 \mathrm{~min}$. The run time was $50.17 \mathrm{~min}$.

Butterfat was used (reference material CRM 164; European Community Bureau of Reference, Brussels, Belgium) to determine the response factor of the FA individually. A standard of 37 components was also used for the identification of the FA (37 Component FAME Mix analytical standard, Supelco No. Cat. 47885-U. 33; Luna et al., 2008; Chilliard et al., 2009).

Isomers of the CLA were analyzed in a HPLC, Hitachi model Elite Chrom, UV/Vis detector (Hitachi High Technologies Corporation, Japan), at a wavelength of $233 \mathrm{~nm}$, using the software EZChrom Elite-Enterprise (Agilent Technologies, Santa Clara, CA) for the integration of the chromatograms. The column used was stainless steel with $4.6 \mathrm{~mm}$ internal diameter $\times 250$ $\mathrm{mm}$ in length and $5 \mu \mathrm{m}$ particle size (ChromoSpher 5 lipid column, Varian Chrompack, Varian, Lake Forest, CA). The mobile phase for separation of isomers of the CLA was acetonitrile $0.1 \%$ in hexane, operated isocratically at a flow rate of $1 \mathrm{~mL} / \mathrm{min}$. The injection volume was $30 \mu \mathrm{L}$. For the identification of the different isomers, a mixture of the methyl esters of the CLA (cis9,trans-11; trans-9, cis-11; trans-10,cis-12; cis-10,cis-12; trans-9,trans-11 and small amounts of other isomers cis and trans C18:2; linoleic acid, conjugated methyl ester Sigma catalog no. 05632-250 mg, Sigma, St. Louis, $\mathrm{MO}$ ) was used, and injected with reference material to compare the order of elution of the isomers with that from the existing literature (Adlof, 2003). The amounts of the other isomers of the CLA were calculated from the areas relating to the area of the principal isomer, cis-9,trans-11 (Luna et al., 2008). Results were expressed in milligrams per gram of fat.
Calculations and Experimental Statistical Design. Fat-corrected milk was calculated at 3.5\%, FCM $(\mathrm{kg} / \mathrm{d})=[\mathrm{milk}(\mathrm{kg} / \mathrm{d}) \times 0.432]+[$ fat $(\mathrm{kg} / \mathrm{d}) \times 16.216]$, and ECM was calculated as ECM $=[$ milk $(\mathrm{kg} / \mathrm{d}) \times$ $0.327]+[$ fat $(\mathrm{kg} / \mathrm{d}) \times 12.86]+[$ protein $(\mathrm{kg} / \mathrm{d}) \times 7.65]$ (Dairy Records Management Systems, 2006). The feed efficiency (FE) was calculated using the following formula: $\mathrm{FE}=$ milk yield $(\mathrm{kg} / \mathrm{d}) / \mathrm{DMI}(\mathrm{kg} / \mathrm{d})$; adjusted $\mathrm{FE}=3.5 \% \mathrm{FCM}(\mathrm{kg}) / \mathrm{DMI}(\mathrm{kg})$.

The in vivo experimental data were subjected to ANOVA using the general linear model (GLM) procedure (SAS 8.2, 2002, SAS Institute Inc.) in a Latin square design repeated $3 \times 3$.

$$
\mathrm{Y}_{\mathrm{ijk}}=\mu+\mathrm{P}_{\mathrm{i}}+\mathrm{A}_{\mathrm{j}}+\mathrm{T}_{(\mathrm{k})}+\mathrm{E}_{\mathrm{ijk}},
$$

where $Y_{\mathrm{ijk}}=$ response variable in period $\mathrm{i}$, animal $\mathrm{j}$, and treatment $\mathrm{k} ; \mu=$ overall mean; $\mathrm{P}_{\mathrm{i}}=$ effect of period $\mathrm{i}$; $A_{j}=$ effect of the animal; $T_{(k)}=$ effect of treatment; and $\mathrm{E}_{\mathrm{ijk}}=$ random error.

The in vitro GP data were subjected to ANOVA using the GLM (PROC GLM, 2002, SAS Institute Inc.). The Tukey test $(P<0.05)$ was used to interpret any significant difference between the mean values.

\section{RESULTS AND DISCUSSION}

\section{Chemical Composition of the Diets}

No differences were observed $(P>0.05)$ among the weights of the animals $\left(15.2 \pm 0.48 \mathrm{~kg}\right.$ of $\left.\mathrm{LW}^{0.75}\right)$; with respect to the feed intake $\left(\mathrm{g} / \mathrm{kg}\right.$ of $\left.\mathrm{LW}^{0.75}\right)$, CHigh exhibited a higher $(P<0.05)$ intake of DM (168.5), OM (155.4), NDF (51.7), and ADF (32.5) compared with CLow and the control diet (DM, $145 \pm 13$; $\mathrm{OM}, 134 \pm 12$; NDF $43 \pm 5$; ADF $27 \pm 0.3 \mathrm{~g} / \mathrm{kg}$ of $\mathrm{LW}^{0.75}$, respectively; Supplemental Table S1, https:// doi.org/10.3168/jds.2017-12785). Bernard (1990) and Economides (1998) included sunflower oil or flaxseed, respectively, in diets for goats and found no differences $(P>0.05)$ in DMI among treatments, in contrast to the present study, where it is shown that DMI for CHigh was higher compared with the other treatments.

\section{Digestibility}

No significant differences among treatments were observed $(P>0.05)$ for DM $(704 \pm 21 \mathrm{~g} / \mathrm{kg}), \mathrm{OM}(763$ $\pm 7 \mathrm{~g} / \mathrm{kg})$, NDF $(605 \pm 12 \mathrm{~g} / \mathrm{kg})$, and ADF $(513 \pm$ $23 \mathrm{~g} / \mathrm{kg}$ ) digestibility (Supplemental Table S2, https:// doi.org/10.3168/jds.2017-12785). Silva et al. (2007) observed no significant differences $(P>0.05)$ in NDF digestibility at different inclusion levels of soybean oil 
Table 3. In vitro gas production of the ingredients used in $\operatorname{diets}^{1}$

\begin{tabular}{lccccc}
\hline Item & $\mathrm{b}$ & $\mathrm{c}$ & Lag time & $\mathrm{DMd}_{96 \mathrm{~h}}$ & $\mathrm{RGP}$ \\
\hline Ingredient & & & & & \\
Barley hay & $156^{\mathrm{c}}$ & $0.04^{\mathrm{c}}$ & $5.86^{\mathrm{a}}$ & $72.3^{\mathrm{bc}}$ & $214^{\mathrm{b}}$ \\
Chia seed & $75^{\mathrm{d}}$ & $0.05^{\mathrm{a}}$ & $3.18^{\mathrm{b}}$ & $38.5^{\mathrm{d}}$ & $243^{\mathrm{b}}$ \\
Corn grain & $250^{\mathrm{a}}$ & $0.05^{\mathrm{b}}$ & $3.17^{\mathrm{b}}$ & $86.3^{\mathrm{ab}}$ & $304^{\mathrm{b}}$ \\
Soybean meal & $213^{\mathrm{b}}$ & $0.05^{\mathrm{a}}$ & $2.41^{\mathrm{b}}$ & $89.3^{\mathrm{a}}$ & $245^{\mathrm{b}}$ \\
Corn silage & $264^{\mathrm{a}}$ & $0.04^{\mathrm{bc}}$ & $2.52^{\mathrm{b}}$ & $62.7^{\mathrm{c}}$ & $438^{\mathrm{a}}$ \\
SEM & 6.37 & 0.002 & 0.300 & 3.76 & 27.6 \\
$P$-value & 0.001 & 0.001 & 0.001 & 0.001 & 0.001 \\
\hline
\end{tabular}

${ }^{\mathrm{a}-\mathrm{d}}$ Different superscript letters in the same column indicate significant differences between values.

${ }^{1} \mathrm{~b}=$ total gas production $\left(\mathrm{mL} / \mathrm{g}\right.$ of DM incubated); $\mathrm{c}=$ fermentation time $(\mathrm{h}-1 / 2) ;$ lag time $=$ lag; $\mathrm{DMd}_{96 \mathrm{~h}}=$ proportion of missing DM (\%); RGP = relative gas production ( $\mathrm{mL}$ of gas/g of DM disappearance).

in the diets of dairy goats. The inclusion of soybean oil in the diet reduced total NDF digestibility by $10 \%$, with an observed decrease in DMI over the control diet. Karalazos et al. (1992) observed that NDF digestibility increased in diets containing $17.0,35.5$, and $53.0 \%$ of cottonseed inclusion when compared with the control treatment.

\section{Nitrogen Balance}

Nitrogen intake was higher $(P<0.001)$ for CHigh (38.3 g of $\mathrm{N} / \mathrm{d})$ compared with CLow and control diets (32.7 \pm 3.3; Supplemental Table S3, https://doi. org/10.3168/jds.2017-12785). The N excretion in feces and urine was similar $(P>0.05)$ among treatments $(16.6 \pm 2.5$ and $8.8 \pm 0.96 \mathrm{~g}$ of $\mathrm{N} / \mathrm{d}$, respectively), being positive in all cases.

\section{In Vitro Gas Production}

The parameters of the in vitro gas production of the ingredients used in the diets are presented in Table 3. Differences in gas production for each ingredient $(P<$ $0.001)$ were observed, being higher $(P<0.001)$ in corn silage and corn grain, and lower in chia seed. The fractional rate of degradation $(\mathrm{c})$ was higher $(P<0.001)$ for soybean and corn grain, followed by barley hay and corn silage. The DMd at $96 \mathrm{~h}$ was higher $(P<0.001)$ for soybean and corn grain, followed by barley hay and corn silage, with DMd being lower for chia seed. The RGP was higher $(P<0.05)$ for corn grain than for the other ingredients. Gas production is an indirect measure of the degradation of substrates, particularly from carbohydrates. Furthermore, it is a good estimator for the production of short-chain FA (Blümmel et al., 1999; Liu et al., 2002).

The parameters of the in vitro gas production of the diets were different among treatments $(P<0.002$; Table 4). Increased gas production and the $\mathrm{c}$ fraction were higher for the control treatment than CHigh, where the inclusion of chia seeds affected the fermentation rate. Higher levels of dietary fat ( $>6 \%$ fat as a percentage of DM) have negative effects on rumen fermentation, which are associated with the inhibition of microbial activity, particularly microorganisms with cellulolytic and methanogenic activity (Johnson and McClure, 1973; Devendra and Lewis, 1974). The DMd at 96 h was higher $(P<0.0221)$ for CLow with respect to CHigh, and the RGP was higher for CHigh $(P<0.05)$ followed by control and CLow. Silva et al. (2016) compared flaxseed and chia seed in in vitro cultures, both of which increased the flows of C18:3n-3, C20:4n-6, and

Table 4. In vitro gas production of the diets with different inclusion levels of chia seed ${ }^{1}$

\begin{tabular}{lccccc}
\hline Item & $\mathrm{b}$ & $\mathrm{c}$ & Lag time & $\mathrm{DMd}_{96 \mathrm{~h}}$ & RGP \\
\hline Dietary group $^{2}$ & & & & & \\
Control & $239^{\mathrm{a}}$ & $0.05^{\mathrm{a}}$ & $3.35^{\mathrm{a}}$ & $73^{\mathrm{ab}}$ & 343 \\
CLow & $219^{\mathrm{ab}}$ & $0.05^{\mathrm{b}}$ & $2.63^{\mathrm{b}}$ & $80^{\mathrm{a}}$ & 282 \\
CHigh & $199^{\mathrm{b}}$ & $0.04^{\mathrm{c}}$ & $3.41^{\mathrm{a}}$ & $62^{\mathrm{b}}$ & 347 \\
SEM & 6.89 & 0.0012 & 0.201 & 4.29 & 27.47 \\
$P$-value & 0.002 & 0.001 & 0.020 & 0.022 & 0.197 \\
\hline
\end{tabular}

${ }^{a-c}$ Different superscript letters in the same column indicate significant differences between values.

${ }^{1} \mathrm{~b}=$ total gas production $\left(\mathrm{mL} / \mathrm{g}\right.$ of DM incubated); $\mathrm{c}=$ fermentation time $(\mathrm{h}-1 / 2) ; \mathrm{DMd}_{96 \mathrm{~h}}=$ proportion of DM disappearance $(\mathrm{mg} / 100 \mathrm{mg})$ at $96 \mathrm{~h} ; \mathrm{RGP}=$ relative gas production $(\mathrm{mL}$ of gas $/ \mathrm{g}$ of DM disappearance).

${ }^{2} \mathrm{CLow}=2.7 \%$ chia seed supplementation; $\mathrm{CHigh}=5.5 \%$ chia seed supplementation. 
total PUFA $(P<0.01)$. Both chia seed and flaxseed treatments had higher rumen concentrations of C18:0, indicating that both chia seed and flaxseed FA were extensively biohydrogenated in the rumen.

\section{Production and Chemical Composition of Milk}

When the different levels of chia seed were included in the diet, no differences $(P>0.05)$ were observed among treatments in milk production $(0.715 \pm 0.015$ $\mathrm{kg} / \mathrm{d})$ and FCM $3.5 \%(0.646 \pm 0.018 \mathrm{~kg} / \mathrm{d}$; Supplemental Table S4, https://doi.org/10.3168/jds.2017-12785). Mir et al. (2000) fed dairy goats with 4 inclusion levels of canola oil without observing any effect on milk production. Similarly, Chilliard et al. (2003) and Lock et al. (2008) reported that the supplementation of fats in diets of dairy goats had no effect on milk production. Fernández (1994) observed no changes in milk production after utilizing 2 levels of soybean oil in lactating cows. In contrast, Lu (1993) found a decrease in milk production with the supplementation of animal fat (5\%) in lactating goats; $\mathrm{FE}$ was similar $(P>0.05)$ among treatments $(0.276 \pm 0.16)$, with respect to the protein content in milk $(3.5 \pm 0.23 \mathrm{~g} / 100 \mathrm{~g})$, no differences were observed among treatments $(P>0.05)$. The addition of fat leads to a reduction of rumen fermentable OM, the reduction of the precursors of glucose and the synthesis of microbial protein, and thus later the "pool" of AA available for the synthesis of proteins in the milk. This explains why a lower amount of protein in the milk is observed with respect to the fat content. Some studies have reported a reduction of protein in milk with diets supplemented with fat (Christensen et al., 1994), which depends on the amount supplied. Bartocci et al. (1988) reported that in dairy goats, with an inclusion of cottonseed of $18 \%$, they found a higher percentage of milk fat without affecting the concentration of protein. However, in the present study the fat content was lower than expected $(2.9 \pm 0.09 \mathrm{~g} / 100 \mathrm{~g})$, which was possibly due to the fact that the animals were in the final third of lactation. The results observed by other authors have shown that the increase in the concentration of fat in the diet does not alter the production of milk fat (Grant and Weidner, 1992; Lu, 1993; Pires et al., 1996). For lactose milk content, no differences were observed $(P>0.05)$ among the treatments; Luna et al. (2008) reported differences in goat milk when the diets were supplemented with whole linseed $(1.84 \%)$ and sunflower oil $(0.81 \%)$ compared with the control diet. Ayeb et al. (2016) found no differences in the lactose content of goat milk with the inclusion of dry olive leaves in the diet. The TS in the diet were similar $(P>$
$0.05)$ among treatments $(12 \pm 0.12 \mathrm{~g} / 100)$; Ayeb et al. (2016) observed an increase of the TS when dry olive leaves were included in the diet.

\section{Composition of Fatty Acids in Milk}

The inclusion of chia seeds at 2 levels in the diets of the animals resulted in significant changes $(P<0.05)$ in the profile of FA in the goat milk (Table 5). A decrease $(P<0.05)$ of $3.4 \%$ was observed in the SFA with the inclusion of chia seed (CHigh) with respect to the control diet, mainly due to the decrease in the contents of medium-chain FA (C10:0, C12:0, C14:0, and C16:0) in the milk. Ollier et al. (2009) also observed a reduction of these FA with the inclusion of whole rapeseed at $14.6 \%$ to a diet high in forage, and Bernard et al. (2005) with the inclusion of protected linseed and sunflower oil. This reduction of the medium-chain FA may be due to the fact that they are principally synthesized de novo in the mammary gland and the trans FA produced in the rumen may inhibit the synthesis of FA (Chilliard et al., 2001; Bernard et al., 2005). The above is of interest for human health, given that the FA C14:0 and C16:0 raise the level of cholesterol and are associated with an increase in the incidence of atherosclerosis and coronary diseases (Williams, 2000).

The concentrations of short-chain FA (4:0, 6:0, and 8:0) remained unchanged in the goat milk $(P>0.05)$. Similar results were found in goat milk by Luna et al. (2008) with diets supplemented with whole linseed and sunflower oil, and by Chilliard et al. (2003) for diets supplemented with the oil and seeds of linseed, sunflower oil, lupine, and soybean.

The content of $\mathrm{C} 18: 0$ increased $(P<0.05)$ in goat milk from diets with a higher content of chia seed, due to the complete biohydrogenation of the linoleic and linolenic acids in the rumen to C18:0, given that the release of the lipids in the seeds is slower than in the form of oil (Chilliard et al., 2003; Ollier et al., 2009). Similarly, the content of the MUFA increased, which is principally related to the FA C18:1n-9 cis, coming partially from the biohydrogenation in the rumen of the FA such as linoleic acid (Sanz-Sampelayo et al., 2007 ) and in the mammary gland from the action of the enzyme desaturase $\Delta^{9}$ on stearic acid C18:0 produced in the rumen (Bauman and Griinari, 2003).

Linoleic acid presented the highest concentration of PUFA, although no significant differences $(P>0.05)$ were observed among treatments. This may be due to the biohydrogenation of these FA in the rumen (Chilliard et al., 2007), given that the 18:3n-3 and the 18:2n6 disappear in the rumen at an average of 93 and $85 \%$, 
Table 5. Effect of addition to the diet of chia seeds on the fatty acid profile (g/100 g of FAME) of goat milk

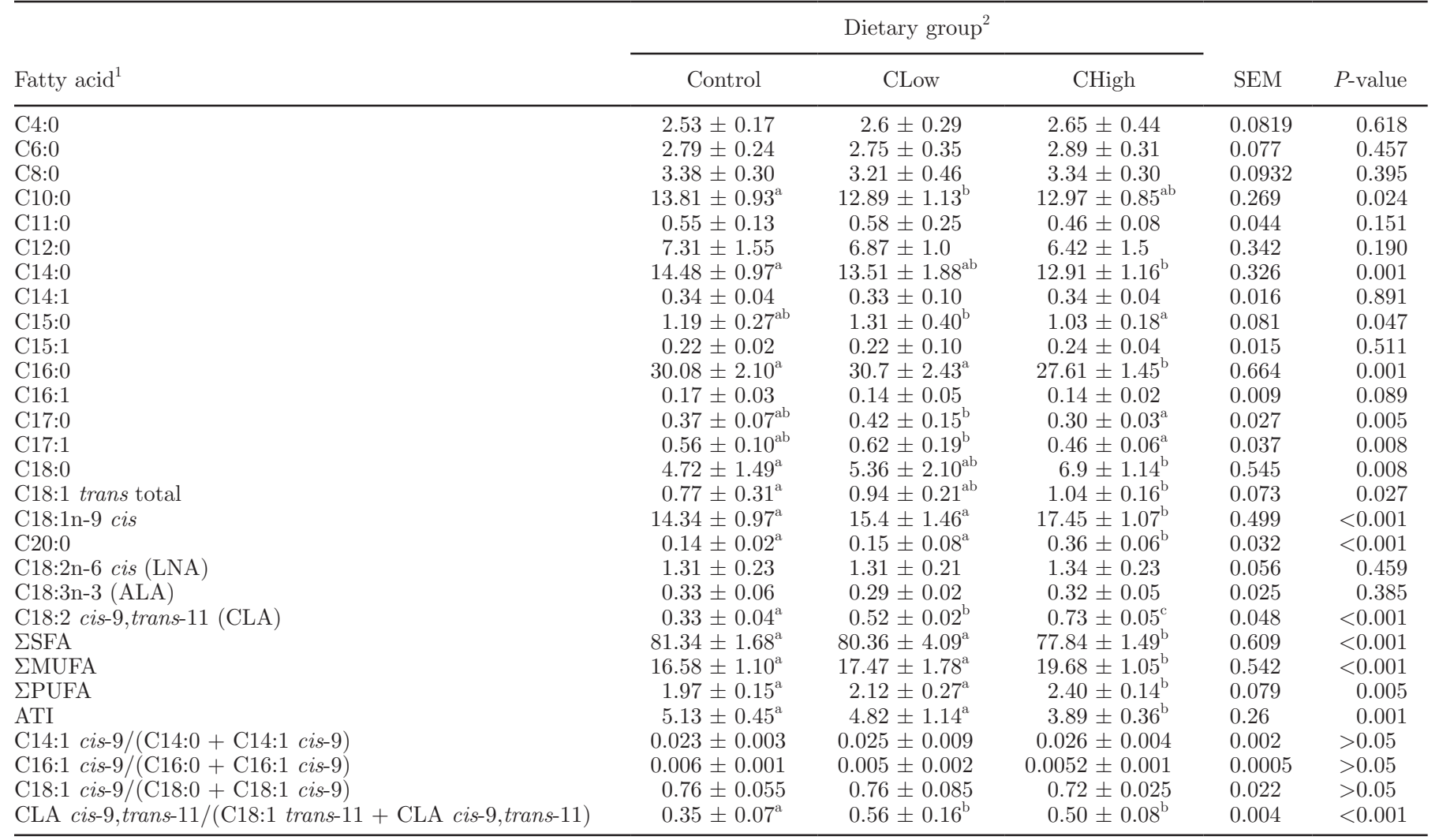

${ }^{\mathrm{a}-\mathrm{c}}$ Different letters in the same row indicate significant differences between values.

${ }^{1} \mathrm{LNA}=$ linoleic acid; ALA $=\alpha$-linolenic acid; ATI $=$ atherogenic index, $(\mathrm{C} 12+4 \mathrm{C} 14+\mathrm{C} 16) /(\mathrm{PUFA}+\mathrm{MUFA})(\mathrm{C} 12+4 \mathrm{C} 14+\mathrm{C} 16) /(\mathrm{PUFA}$ + MUFA) (Ulbricht and Southgate, 1991).

${ }^{2}$ CLow $2.7 \%$ chia seed supplementation; CHigh $=5.5 \%$ chia seed supplementation.

respectively (Bernard et al., 2009). The PUFA content increased $(P<0.05)$ in the diets with chia seed with respect to the control diet.

The inclusion of chia seed increased $(P<0.05)$ the CLA content compared with the control diet. When the diets are supplemented with oil seeds or vegetable oils, these FA can be produced in the rumen through the action of anaerobic bacteria by the isomerization of the linoleic acid to form cis-9,trans-11 C18, or RA and other isomers such as trans-9,cis-11 C18:2; trans10,cis-12 C18:2, and through biohydrogenation from the trans-vaccenic fatty acid (TVA) trans-11, C18:1 (Chilliard and Ferlay, 2004; Chilliard et al., 2007), all of which pass to the blood stream and are absorbed in the mammary gland. The TVA is reduced by the $\Delta^{9}$-desaturase enzymes and forms the FA cis-9,trans-11 C18:2, among other isomers. It has been estimated that between 64 and $97 \%$ of the RA present in milk comes from the endogenous synthesis of the TVA in the mammary gland. These enzymes can also act on myristic, palmitic, and stearic acids (Chilliard et al., 2007; Manso et al., 2016). These results correspond to the desaturation index $(\mathrm{C} 14: 1 / \mathrm{C} 14)$, an estimator of the activity of the enzyme $\Delta^{9}$-desaturase (Renna et al., 2012), which increased $(P<0.05)$ with the inclusion of the chia seed in the present study, which indicates that the activity of the stearol-CoA desaturase (SCD) in the mammary gland did not decrease. This is in contrast to the results of Luna et al. (2008), who observed a decrease in the activity of the enzyme with the inclusion of whole linseed and sunflower oil in the diets. Bernard et al. (2005) supplemented diets with protected linseed and sunflower seed oils, and observed a decrease in the activity of the enzyme SCD, suggesting a negative regulation of SCD by a diet containing PUFA and long-chain FA and by the products of the biohydrogenation in the rumen, such as trans C18:1 or trans C18:2. This difference may have been due to the fact that the release of the lipids in the chia seeds is slower than in the form of oil, and therefore a complete biohydrogenation of the PUFA occurs. The results of ratios compared with those obtained by Chilliard et al. (2009) in cow milk with diets that included raw and extruded linseed and linseed oil showed that the ratios 
Table 6. Conjugated linoleic acid isomers ( $\mathrm{mg} / \mathrm{g}$ of CLA) as determined by silver ion HPLC

\begin{tabular}{|c|c|c|c|c|c|}
\hline \multirow[b]{2}{*}{ Item } & \multicolumn{3}{|c|}{ Dietary group $^{1}$} & \multirow[b]{2}{*}{ SEM } & \multirow[b]{2}{*}{$P$-value } \\
\hline & Control & CLow & CHigh & & \\
\hline \multicolumn{6}{|l|}{ Isomer } \\
\hline trans-12,trans-14 & $0.035^{\mathrm{a}}$ & $0.0137^{\mathrm{b}}$ & $0.067^{\mathrm{c}}$ & 0.0067 & $<0.001$ \\
\hline trans-11,trans-13 & $0.004^{\mathrm{a}}$ & $0.0219^{\mathrm{a}}$ & $0.068^{\mathrm{b}}$ & 0.0092 & $<0.001$ \\
\hline trans-10,trans- 12 & $0.020^{\mathrm{a}}$ & $0.029^{\mathrm{a}}$ & $0.054^{\mathrm{b}}$ & 0.0082 & 0.007 \\
\hline trans- 9, trans- 11 & $0.015^{\mathrm{a}}$ & $0.020^{\mathrm{a}}$ & $0.055^{\mathrm{b}}$ & 0.0078 & $<0.001$ \\
\hline trans- 8 , trans -10 & $0.020^{\mathrm{a}}$ & $0.041^{\mathrm{b}}$ & $0.029^{\mathrm{ab}}$ & 0.0044 & 0.002 \\
\hline trans-7,trans-9 & $0.030^{\mathrm{a}}$ & $0.020^{\mathrm{a}}$ & $0.064^{\mathrm{b}}$ & 0.0089 & 0.001 \\
\hline$\Sigma$ trans,trans & $0.124^{\mathrm{a}}$ & $0.146^{\mathrm{a}}$ & $0.339^{\mathrm{b}}$ & 0.0296 & $<0.001$ \\
\hline trans-11, cis-13 & $0.018^{\mathrm{a}}$ & $0.044^{\mathrm{a}}$ & $0.171^{\mathrm{b}}$ & 0.0289 & $<0.001$ \\
\hline $10,12{\text { (cis } / \text { trans })^{2}}^{2}$ & $0.003^{\mathrm{a}}$ & $0.016^{\mathrm{a}}$ & $0.062^{\mathrm{b}}$ & 0.0105 & $<0.001$ \\
\hline $9,11{\text { (cis/trans })^{2}}^{2}$ & $3.049^{\mathrm{a}}$ & $4.694^{\mathrm{b}}$ & $6.461^{\mathrm{c}}$ & 0.4413 & $<0.001$ \\
\hline $7,9(\text { cis } / \text { trans })^{2}$ & $0.165^{\mathrm{a}}$ & $0.428^{\mathrm{b}}$ & $0.358^{\mathrm{ab}}$ & 0.0667 & 0.013 \\
\hline$\Sigma$ cis/trans & $3.238^{\mathrm{a}}$ & $5.184^{\mathrm{b}}$ & $7.053^{\mathrm{c}}$ & 0.4677 & $<0.001$ \\
\hline
\end{tabular}

${ }^{a-c}$ Different superscript letters in the same row indicate significant differences between values.

${ }^{1}$ CLow $2.7 \%$ chia seed supplementation; CHigh $=5.5 \%$ chia seed supplementation.

${ }^{2}$ cis $/$ trans $=$ cis-trans + trans-cis.

of $\mathrm{C} 14: 1$ cis-9/C14:0 + C14:1 cis-9 and $\mathrm{C} 16: 1$ cis-9/ $\mathrm{C} 16: 0+\mathrm{C} 16: 1$ cis-9 were lower and similar to the ratio of $\mathrm{C} 18: 1$ cis-9/C18:0 + C18:1 cis-9, CLA/C18:1 trans + CLA.

It is observed that the atherogenicity index decreases with the inclusion of chia by as much as $25 \%$. Renna et al. (2012), varying the proportion of forage in goat diets, found a decrease of $40 \%$ in the atherogenicity index with the inclusion of sunflower seed in the diet. In Chilliard et al. (2003), goats fed a low-forage diet supplemented with linseed and sunflower seeds had the atherogenicity index decreased 45 and 50\%, respectively.

\section{Isomers of CLA}

The distribution of the content of the isomers of CLA is shown in Table 6. The most abundant isomer is cis9,trans-11 C18:2 (87 to 90\% of the total CLA), from the rumen and the endogenous synthesis of the trans-11 C18:1, by action of the enzyme $\Delta^{9}$-desaturase in the mammary gland.

The isomer trans-7,cis-9 C18:2 represents, after RA, the second most representative CLA isomer in milk fat (Secchiari et al., 2003) and is synthesized by the action of the enzyme $\Delta^{9}$-desaturase in the mammary gland on trans-7 C18:1 (Rego et al., 2009). It has been found that this isomer is increased when the diets of goats are supplemented with high-oleic sunflower oil (Ferlay et al., 2003). In our case, with the inclusion of chia seeds, values between 5 and $8 \%$ of the total of CLA were reached. Rego et al. (2009) found in the fat of cow milk percentages of $8.4 \%$ of this isomer with the inclusion of rapeseed oil in the diet and 3\% for diets supplemented with oil of sunflower and linseed. The content of the isomer trans-10,cis-12 C18:2 in the milk increased with the inclusion of chia seed. This isomer is formed in the rumen through the action of anaerobic bacteria; the enzymes present carry out the isomerization of the linoleic acid found in the seeds (Griinari and Bauman, 1999). This FA has been associated with a higher risk of coronary diseases and also with negative effects on the productive yields of milk in the animals, associated with the syndrome of milk fat depression (Manso et al., 2016). In our results, the content of this FA was lower than $1 \%$ of the total of the CLA isomers. These results agree with Chilliard et al. (2007), Lock et al. (2008), and Luna et al. (2008). It has been found that when there is an increase in the diets in the amount of concentrate, which includes easily degraded carbohydrates and seeds rich in PUFA, the bacterial population of the rumen increases, which produces significant amounts of these 2 FA, the isomer trans-7,cis-9, and trans-10,cis-12 C18:2 (Piperova et al., 2000).

The isomer trans-11,cis-13 also increased by as much as $2.3 \%$ with the inclusion of chia seed (CHigh) in the diet. Bernard et al. (2009) found that the incorporation of seeds or seed oil containing linolenic acid increases this isomer.

The isomer trans-9,trans-11 C18:2 inhibits the enzyme $\Delta^{9}$-desaturase in bovine (Perfield et al., 2007). The amount of this isomer increased in the diets that contained chia seed, although the values were lower than those found by Luna et al. (2008) and Bernard et al. (2009) with the incorporation of sunflower or linseed oils in goat diets. The sum of these trans-trans isomers was less than $5 \%$ of the total CLA. Similar values were found by Luna et al. (2008); most of these isomers increased with the inclusion of chia (CHigh), with trans-12,trans-14 and trans-11,trans-13 showing 
the highest increase, due to the presence of linolenic acid in the chia seed incorporated in the diet (Collomb et al., 2004; Sanz-Sampelayo et al., 2007).

\section{CONCLUSIONS}

Adding chia seed to diets for dairy goats negatively affected in vitro rumen fermentation compared with the control diet. The inclusion of $5.5 \%$ of chia seed diminished the C14:0 and C16:0 FA in milk and improved the C18:1, C18:2, and C20:0 content in milk fat, increasing the PUFA concentration up to $20 \%$ and all the isomers of CLA, being healthier for the human consumption, without affecting milk yield production and chemical composition.

\section{ACKNOWLEDGMENTS}

Jose Romero was awarded a Consejo Nacional de Ciencia y Tecnología (CONACyT), Mexico, scholarship for his studies in the Universidad Autonoma del Estado de Mexico. Gonzalez Ronquillo was awarded the CONACyT fellowship Estancias Sabaticas en el Extranjero 2014. Also, we thank Penelope Krumm (Hamburg, Germany) for the language review of this paper. This project was supported by the Universidad Autonoma del Estado de Mexico 3060/2011.

\section{REFERENCES}

Adlof, R. O. 2003. Application of silver-ion chromatography to the separation of conjugated linoleic acid isomers. Pages 37-56 in Advances in Conjugated Linoleic Acid Research. Vol. 2. J. L. Sébédio, W. W. Christie, and R. Adlof, ed. AOCS Press, Champaign, IL.

Alvarez, C. M., L. M. A. Valdivia, J. M. L. Aburto, and C. A. Tecante. 2008. Chemical characterization of the lipid fraction of Mexican chia seed (Salvia hispanica). Int. J. Food Prop. 11:687-697.

AOAC. 1990. Official Methods for Analysis of the Association Official Analytical Chemists, 15th ed., Vol. 1. AOAC, Washington, DC.

AOAC International. 2005. Official Methods of Analysis, 18th ed. AOAC International, Gaithersburg, MD.

Aydin, R. 2005. Conjugated linoleic acid: Chemical structure, source and biological properties. Turk. J. Vet. Anim. Sci. 29:189-195.

Ayeb, N., M. Addis, M. Fiori, S. Khorchani, M. Atigu, and T. Khorchani. 2016. Quality and fatty acid profile of the milk of indigenous goats subjected to different local diets in Tunisian arid lands. J. Anim. Physiol. Anim. Nutr. (Berl.) 100:101-108.

Azcona, J. O., M. J. Schang, P. T. Garcia, C. Gallinger Jr., R. Ayerza, and W. Coates. 2008. Omega-3 enriched broiler meat: The influence of dietary-linolenic-3 fatty acid sources on growth, performance and meat fatty acid composition. Can. J. Anim. Sci. $88: 257-269$.

Bartocci, S., G. M. Terzano, A. Omero, and A. Borghese. 1988. Utilizzazione del seme integrale di cotone nella dieta di capre in lattazione. Pt. 1. Ann. Dell Istituto Sper. Zootec. Roma. 21.

Bauman, D. E., and J. M. Griinari. 2003. Nutritional regulation of milk fat synthesis. Annu. Rev. Nutr. 23:203-227.

Bernard, J. K. 1990. Effect of raw or roasted whole soybeans on digestibility of dietary nutrients and milk production of lactating dairy cows. J. Dairy Sci. 73:3231-3236.

Bernard, L., J. Rouel, C. Leroux, A. Ferlay, Y. Faulconnier, P. Legrand, and Y. Chilliard. 2005. Mammary lipid metabolism and milk fatty acid secretion in alpine goats fed vegetable lipids. J. Dairy Sci. 88:1478-1489.

Bernard, L., J. K. Shingfield, J. Rouel, A. Ferlay, and Y. Chilliard. 2009. Effect of plant oils in the diet on performance and milk fatty acid composition in goats fed diets based on grass hay or maize silage. Br. J. Nutr. 101:213-224.

Blümmel, M., K. P. Aiple, H. Steingass, and K. Becker. 1999. A note on the stoichiometrical relationship of short chain fatty acid production and gas formation in vitro in feedstuffs of widely differing quality. J. Anim. Physiol. Anim. Nutr. (Berl.) 81:157-167.

Chen, S., G. Bobe, S. Zimmerman, E. G. Hammond, C. M. Luhman, T. D. Boylston, A. E. Freeman, and D. C. Beitz. 2004. Physical and sensory properties of dairy products from cows with various milk fatty acid compositions. J. Agric. Food Chem. 52:3422-3428.

Chilliard, Y., and A. Ferlay. 2004. Dietary lipids and forages interactions on cow and goat milk fatty acid composition and sensory properties. Reprod. Nutr. Dev. 44:467-492.

Chilliard, Y., A. Ferlay, and M. Doreau. 2001. Effect of different types of forages, animal fat or marine oils in cow's diet on milk fat secretion and composition, especially conjugated linoleic acid (CLA) and polyunsaturated fatty acids. Livest. Prod. Sci. 70:31-48.

Chilliard, Y., A. Ferlay, J. Rouel, and G. Lamberet. 2003. A review of nutritional and physiological factors affecting goat milk lipid synthesis and lipolysis. J. Dairy Sci. 86:1751-1770.

Chilliard, Y., F. Glasser, A. Ferlay, L. Bernard, J. Rouel, and M. Doreau. 2007. Diet, rumen biohydrogenation and nutritional quality of cow and goat milk fat. Eur. J. Lipid Sci. Technol. 109:828855.

Chilliard, Y., C. Martin, J. Rouel, and M. Doreau. 2009. Milk fatty acids in dairy cows fed whole crude linseed, extruded linseed, or linseed oil, and their relationship with methane output. J. Dairy Sci. 92:5199-5211.

Christensen, R. A., J. K. Drackley, D. W. LaCount, and J. H. Clark. 1994. Infusion of four long-chain fatty acid mixtures into the abomasum of lactating dairy cows. J. Dairy Sci. 77:1052-1069.

Collomb, M., R. Sieber, and U. Bütikofer. 2004. CLA isomers in milk fat from cows fed diets with high levels of unsaturated fatty acids. Lipids 39:355-364.

Connor, S. L., S. M. Artaud-Wild, C. J. Classick-Kohn, J. R. Gustafson, D. P. Flavell, L. F. Hatcher, and W. E. Connor. 1986. The cholesterol/saturated-fat index: Indication of the hypercholesterolaemic and atherogenic potential of food. Lancet 328:1229-1232.

Dairy Records Management Systems. 2006. DHI Glossary. Accessed Apr. 5, 2017. http://www.drms.org.

Devendra, C., and D. Lewis. 1974. The interaction between dietary lipids and fiber in the sheep. 2. Digestibility studies. Anim. Prod. 19:67-76.

Dewhurst, R. J., K. J. Shingfield, M. R. F. Lee, and N. D. Scollan. 2006. Increasing the concentrations of beneficial polyunsaturated fatty acids in milk produced by dairy cows in high-forage systems. Anim. Feed Sci. Technol. 131:168-206.

Economides, S. 1998. The nutritive value of sunflower meal and its effect on replacing cereal straw in the diets of lactating ewes and goats. Livest. Prod. Sci. 55:89-97.

Ewing, I. W. N. 1997. The FEEDS directory. Page 220 in Branded Products Guide. CONTEXT Products Ltd. Publications Division, UK.

Ferlay, A., J. Rouel, J. M. Chabosseau, P. Capitan, K. Raynal-Ljutovac, and Y. Chilliard. 2003. Interactions between ryegrass preservation and high-oleic sunflower oil supplementation on goat milk composition, including trans and conjugated fatty acids. Page 350 in Abstracts, 54th Annual Meeting of European Association for Animal Production. Y. van Der Honing, ed. Wageningen Academic Publishers (NL), Rome, Italy.

Fernández, A. M. 1994. The use of raw soybeans in the production of dairy cows. Master Thesis. Universidad Federal de Lavras, Brasil (In Portuguese)

Frank, C., E. H. Smith, H. E. Brauwn, A. Holdrinet, and J. W. McWade. 1975. Organochlorine insecticides and industrial pollutants in the milk supply of the Southern Region of Ontario, Canada. J. Milk Food Technol. 38:65-72. 
Grant, R. J., and S. J. Weidner. 1992. Effect of fat from whole soybeans on performance of dairy cows fed rations differing in fiber level and particle size. J. Dairy Sci. 75:2742-2751.

Griinari, J. M., and D. E. Bauman. 1999. Biosynthesis of conjugated linoleic acid and its incorporation into meat and milk in ruminant. Pages 180-200 in Advances in conjugated Linoleic Acid Research. Vol. 1. M. P. Yurawecz, M. M. Mossoba, J. K. G. Kramer, M. W. Pariza, and G. L. Nelson, ed. AOCS Press, Champaign, IL.

Haenlein, G. F. W. 2004. Goat milk in human nutrition. Small Rumin. Res. 51:155-163.

Hilario,, M. C., D. C. Puga, N. Wrage, and R. F. Pérez-Gil. 2010. Feeding goats on scrubby Mexican rangeland and pasteurization: Influences on milk and artisan cheese quality. Trop. Anim. Health Prod. 42:1127-1134.

ISO-IDF. 2002. Milk fat-Preparation of fatty acid methyl esters. International Standard ISO 15884-IDF 182:2002. International Organisation for Standardisation (ISO), Geneva, Switzerland.

Johnson, R. R., and K. E. McClure. 1973. High fat rations for ruminants. II. Effects of fat added to corn plant material prior to ensiling on digestibility and voluntary intake of the silage. J. Anim. Sci. 36:397-406

Karalazos, A., D. Dotas, and J. Bikos. 1992. A note on the apparent digestibility and nutritive value of whole cottonseed given to sheep. Anim. Prod. 55:285-287.

Krishnamoorthy, U., H. Soller, H. Steingass, and K. H. Menke. 1991. A comparative study on rumen fermentation of energy supplements in vitro. J. Anim. Physiol. Anim. Nutr. (Berl.) 65:28-35.

Liu, J. X., A. Susenbeth, and K. H. Südekum. 2002. In vitro gas production measurements evaluate interactions between untreated and chemically treated with rice straws, grass hay, and mulberry leaves. J. Anim. Sci. 80:517-524.

Lock, A. L., M. Rovai, T. A. Gipson, M. J. de Veth, and D. E. Bauman. 2008. A conjugated linoleic acid supplement containing trans-10, cis-12 conjugated linoleic acid reduces milk fat synthesis in lactating goats. J. Dairy Sci. 91:3291-3299.

Lu, C. D. 1993. Implication of feeding isoenergetic diets containing animal fat on milk composition of alpine does during early lactation. J. Dairy Sci. 76:1137-1147.

Luna, P., A. Bach, M. Juárez, and M. A. De la Fuente. 2008. Effect of a diet enriched in whole linseed and sunflower oil on goat milk fatty acid composition and conjugated linoleic acid isomer profile. J. Dairy Sci. 91:20-28.

Manso, T., B. Gallardo, and C. Guerra-Rivas. 2016. Modifying milk and meat fat quality through feed changes. Small Rumin. Res. 142:31-37.

Menke, K. H., and H. Steingass. 1988. Estimation of the energetic feed value obtained from chemical analysis and in vitro gas production using rumen fluid. Anim. Res. Dev. 28:7-55.

Mir, Z., M. L. Rushfeldt, P. S. Mir, L. J. Paterson, and R. J. Weselake. 2000. Effect of dietary supplementation with either conjugated linoleic acid (CLA) or linoleic acid rich oil on the CLA content of lamb tissues. Small Rumin. Res. 36:25-31.

NRC. 2007. Nutrient Requirements of Small Ruminants: Sheep, goats, cervids, and new world camelids. National Academy Press, Washington, DC.

Ollier, S., C. Leroux, A. de la Foye, L. Bernard, J. Rouel, and Y. Chilliard. 2009. Whole intact rapeseeds or sunflower oil in high- forage or high-concentrate diets affects milk yield, milk composition, and mammary gene expression profile in goats. J. Dairy Sci. 92:5544-5560.

Perfield, J. W., A. L. Lock, J. M. Griinari, A. Sæbø, P. Delmonte, D. A. Dwyer, and D. E. Bauman. 2007. Trans-9, cis-11 conjugated linoleic acid reduces milk fat synthesis in lactating dairy cows. J. Dairy Sci. 90:2211-2218.

Piperova, L. S., B. B. Teter, I. Bruckental, J. Sampugna, S. E. Mills, M. P. Yurawecz, J. Fritsche, K. Ku, and R. A. Erdman. 2000. Mammary lipogenic enzyme activity trans fatty acids and conjugated linoleic acids are altered in lactation cows fed a milk fatdepressing diet. J. Nutr. 130:2568-2574.

Pires, A. V.. M. L. Eastridge, and J. L. Firkins. 1996. Roasted soybeans, blood meal, and tallow as sources of fat and ruminally undegradable protein in the diets of lactating cows. J. Dairy Sci. 79:1603-1610.

Prandini, A., S. Sigolo, and G. Piva. 2011. A comparative study of fatty acid composition and CLA concentration in commercial cheeses. J. Food Compos. Anal. 24:55-61.

Rego, O. A., S. P. Alves, L. M. S. Antunes, H. J. D. Rosa, C. F. M. Alfaia, J. A. M. Prates, A. R. J. Cabrita, A. J. M. Fonseca, and R. J. B. Bessa. 2009. Rumen biohydrogenation-derived fatty acids in milk fat from grazing dairy cows supplemented with rapeseed, sunflower or linseed oils. J. Dairy Sci. 92:4530-4540.

Renna, M., P. Cornale, C. Lussiana, V. Malfatto, A. Mimosi, and L. M. Battaglini. 2012. Fatty acid profile of milk from goats fed diets with different levels of conserved and fresh forages. Int. J. Dairy Technol. 65:20-27.

Sanz Sampelayo, M. R., Y. Chilliard, P. Schmidely, and J. Boza. 2007. Influence of type of diet on the fat constituents of goat and sheep milk. Small Rumin. Res. 68:42-63.

Secchiari, P., M. Antongiovanni, M. Mele, A. Serra, A. Buccioni, G. Ferruzi, F. Paoletti, and F. Petachi. 2003. Effect of kind of dietary fat on the quality of milk fat from Italian Frisian cows. Livest. Prod. Sci. 83:43-52.

Silva, L. G., J. Bunkers, E. M. Paula, T. Shenkoru, Y. Yeh, B. Amorati, D. Holcombe, and A. P. Faciola. 2016. Effects of flaxseed and chia seed on ruminal fermentation, nutrient digestibility, and longchain fatty acid flow in a dual-flow continuous culture system. J. Anim. Sci. 94:1600-1609.

Silva, M. M., M. T. Rodrigues, R. H. Branco, C. A. Rodrigues, J. L. Sarmento, A. C. Queiroz, and S. P. Silva. 2007. Suplementação de lipídios em dietas para cabras em lactação: Consumo e eficiência de utilização de nutrientes. Rev. Bras. Zootec. 36:257-267.

Theodorou, M. K., B. A. Williams, M. S. Dhanoa, A. B. Mc Allan, and J. France. 1994. A simple gas production method using a pressure transducer to determine the fermentation kinetics of ruminant feeds. Anim. Feed Sci. Technol. 48:185-197.

Ulbricht, T. L. V., and D. A. T. Southgate. 1991. Coronary heart disease: Seven dietary factors. Lancet 338:985-992.

Van Soest, P. J., J. B. Robertson, and B. A. Lewis. 1991. Symposium: Carbohydrate methodology, metabolism, and nutritional implications in dairy cattle. Methods for dietary fiber, neutral detergent fiber and non-starch polysaccharides in relation to animal nutrition. J. Dairy Sci. 74:3583-3597.

Williams, C. M. 2000. Dietary fatty acids and human health. Ann. Zootech. 49:165-180. 